\title{
Ultrastructural Alterations in Lepocinclis acus (Euglenophyta) Induced by Medium with High Organic Matter Content
}

\author{
Visitación T. Conforti ${ }^{1 *}$, Laura B. Ruiz ${ }^{2}$ and Patricia I. Leonardi ${ }^{3,4}$ \\ ${ }^{1}$ Departamento de Biodiversidad y Biología Experimental, Facultad de Ciencias Exactas y Naturales, Instituto de \\ Biodiversidad y Biología Experimental y Aplicada, CONICET-Universidad de Buenos Aires, Buenos Aires, Argentina, \\ ${ }^{2}$ Departamento de Biodiversidad y Biología Experimental, Facultad de Ciencias Exactas y Naturales, CONICET-Universidad \\ de Buenos Aires, Buenos Aires, Argentina, ${ }^{3}$ Centro de Recursos Naturales Renovables de la Zona Semiárida CONICET, \\ Bahía Blanca, Argentina, ${ }^{4}$ Departamento de Biología, Bioquímica y Farmacia, Universidad Nacional del Sur, Bahía Blanca, \\ Argentina
}

\section{OPEN ACCESS}

Edited by:

Eric Wade Linton, Central Michigan University,

United States

Reviewed by:

Ugo Cenci,

Lille University of Science and

Technology, France

Neil W. Blackstone,

Northern Illinois University,

United States

*Correspondence:

Visitación T. Confort

conforti@bg.fcen.uba.ar

Specialty section:

This article was submitted to

Phylogenetics, Phylogenomics, and

Systematics,

a section of the journal

Frontiers in Ecology and Evolution

Received: 22 May 2017 Accepted: 07 November 2017 Published: 21 November 2017

Citation:

Conforti VT, Ruiz LB and Leonardi PI (2017) Ultrastructural Alterations in Lepocinclis acus (Euglenophyta) Induced by Medium with High Organic Matter Content.

Front. Ecol. Evol. 5:141. doi: 10.3389/fevo.2017.00141
Ultrastructural changes induced by exposure to excess of organic matter were studied in Lepocinclis acus (ex Euglena acus). The cells isolated from the Matanza River, Buenos Aires, Argentina, were grown in soil water medium (SWM). When transferred to medium enriched with Bacteriological Peptone OXOID ${ }^{\circledR}$, marked body deformation and a significant shortening and widening of the cells was observed. These changes were unexpected in a species with quite rigid cells, a condition previously shown in studies of the pellicle fine structure. Transmission electron microscopy observations suggest that cellular deformation might be facilitated by an increase in strip number, whereas in the original strips normal ultrastructure was maintained. An increase in number and volume of paramylon grains and vacuoles, as well as the presence of membrane whorls in vacuoles was observed. The fine structure of organisms grown in medium with and without organic matter enrichment was compared, and the systematic and ecological importance of morphological changes triggered by cell deformation was discussed.

\section{Keywords: Euglenoids, Lepocinclis acus, microalgae, organic matter, ultrastructure}

\section{INTRODUCTION}

Euglenoids are a diverse group of unicellular, asexual microalgae that most commonly have two flagella, one or both may be emergent. Many are heterotrophic and others are photosynthetic, having acquired a chloroplast via secondary endosymbiosis of a eukaryotic green alga (Leander, 2004; Nozaki, 2005). One of its principal characteristics is the pellicle. It is a complex cell surface structure composed of the plasma membrane, proteins strips lying beneath the membrane, several microtubules associated with the strips and vesicles of endoplasmic reticulum. The principal part of a strip is a sigmoidal frame in transverse section (Leander and Farmer, 2001). A cross-section of a cell shows the pellicle organized as a series of ridges and grooves. Strips are arranged in parallel with a longitudinal or helicoidal orientation. This structure is multigenerational; each strip or set of strips represents a different cytokinetic event in the development of any particular cell (Esson and Leander, 2006, 2008). Before the cell cytokinesis, the total number of pellicle strips is doubled, emerging the new ones within the articulation zones between old strips. In this way, each new cell inherits the same number of pellicle strips as the parent cell in a semi-conservative mode. 
Other particular feature of euglenoiods is the presence of paramylon grains, distributed in the cell cytoplasm, as storage carbohydrate or energy reserve. They show great variety in shapes and number within the different species.

Human activities have drastically altered the chemistry, and particularly the nutrient concentration of many freshwater bodies (Conforti et al., 1995; Dokulil, 1996; Conforti, 1998; Paul and Meyer, 2001, 2008; O'Farrell et al., 2002). Microalgae of these affected environments, depending on the characteristics and concentration of the pollutants, may suffer changes in their number, morphology, and ecophysiology. Excessive enrichment of freshwater bodies with organic matter is mainly caused by industrial, domestic and agricultural processes. Euglenoids are a group of microalgae, which usually increases its abundance in these kinds of environments (Lackey, 1968; Munawar, 1972; Rosowski, 2003). Among these Lepocinclis acus is one of the species very commonly shown in these conditions (Conforti et al., 1995), for this reason it was chosen for this study.

Previous works describe different responses of euglenoids to those conditions and report the existence of taxa containing either numerous small or few but larger paramylon grains, which are supposedly related to the high concentration of organic matter in the freshwater body studied (Conforti, 1991; Conforti et al., 1995). L. acus and other euglenoids species cultured or sampled in enriched medium and studied with light microscopy (Haughey, 1970; Conforti, 1998; Bauer et al., 2012; Nannavecchia et al., 2014) showed important morphological changes that were related to an increase in the number or size of paramylon grains. Precise biometric measurements have revealed significant statistical differences in the dimensions and number of the grains between the treated and control specimens.

For many years, euglenoids cell plasticity and its sensitivity to environmental conditions have been studied (Bertaux and Valencia, 1973; Bre and Lefort-Tran, 1978; Kiss et al., 1986). In the case of $L$. acus, these changes were difficult to explain since this species has always been described by previous studies of the pellicle fine structure as an organism with rigid or slightly flexible cells (Mignot, 1965; Bricheux and Brugerolle, 1986). In this paper, the ultrastructural modifications induced by the excess of organic matter in the medium are described, the development response patterns indicating an evolutionary difference among euglenoids and their ecological implications are discussed.

\section{MATERIALS AND METHODS \\ Cell Culture}

Lepocinclis acus (O. F. Müller) Marin et Melkonian was isolated from Matanza River $\left(34^{\circ} 44^{\prime} 27.45^{\prime \prime} \mathrm{S} 58^{\circ} 31^{\prime} 14.12^{\prime \prime} \mathrm{W}\right)$, Buenos Aires, Argentina, by one of the authors (L R). Samples were filtered with a plankton-net (mesh size $20 \mu \mathrm{m}$ ). An unialgal culture was obtained using Pasteur capillary pipettes. Single cells were washed twice with physiological solution, and poured into glass tubes containing Soil Water Medium (SWM; Pringsheim, 1946). After 2 months, a stable culture developed. Stock cultures were maintained in SWM at room temperature (ca. $23^{\circ} \mathrm{C}$ ) on a $12 / 12 \mathrm{~h}$ dark/light cycle with $25-35 \mu \mathrm{E} / \mathrm{m}^{2} / \mathrm{s}$ illumination provided by 40 -watt, cool white, fluorescent bulbs. L. acus is generally characterized by cylindrical to fusiform, very slender cells (65-300 $\mu \mathrm{m}$ long, 7-28 $\mu \mathrm{m}$ wide, 7-20 length/width ratio) containing several discoid chloroplasts ( $<5 \mu \mathrm{m}$ diameter). Strain obtained and cultured for assays purposes ranged $277 \mu \mathrm{m} \pm$ 64 length, $21 \mu \mathrm{m} \pm 2$ width, mean length/width ratio $13 \pm 1$ (Figure 1a). Two or more rod shaped paramylon bodies are usually located before and behind the central nucleus $(30 \mu \mathrm{m} \pm$ 2 length, $6 \mu \mathrm{m} \pm 1$ width). These characteristics were set up as "normal cells."

\section{Assays}

A solution of Bacteriological Peptone OXOID ${ }^{\circledR} \quad$ [Typical analysis: Total Nitrogen $14 \% \mathrm{w} / \mathrm{w}$, Amino Nitrogen $2.6 \% \mathrm{w} / \mathrm{w}$, Sodium chloride $1.6 \%, \mathrm{pH}$ ( $1 \%$ solution) 6.3 at $25^{\circ} \mathrm{C}$ ), hereafter called BP, 3\% (w/v) with the SWM supernatant was prepared. Stock cultures were inoculated in test tubes containing $5 \mathrm{ml}$ of solution of BP to a final concentration of $100 \mathrm{cell} / \mathrm{ml}$. Control tubes were prepared with $5 \mathrm{ml}$ of SWM supernatant.

The assays were performed using five tubes as control (SWM supernatant) and five tubes containing the solution prepared with SWM supernatant and BP. The assays were carried out at room temperature $\left(\mathrm{ca} .23^{\circ} \mathrm{C}\right.$ ) on a $12 / 12 \mathrm{~h}$ dark/light cycle with $25-35 \mu \mathrm{E} / \mathrm{m} 2 / \mathrm{s}$ illumination provided by 40 -watt, cool white, fluorescent bulbs. Control and treated tubes were kept at stock conditions for $48 \mathrm{~h}$. The number of cells per $\mathrm{mL}$ of each tube was counted with a Neubauer chamber. Measurements were taken on 100 cells/tube: the length and width and number and size of paramylon grains. A Lilliefors test was performed to evaluate the normal distribution. The test was carried out with Statistica v. 8 software. The mean and standard deviation was obtained in each

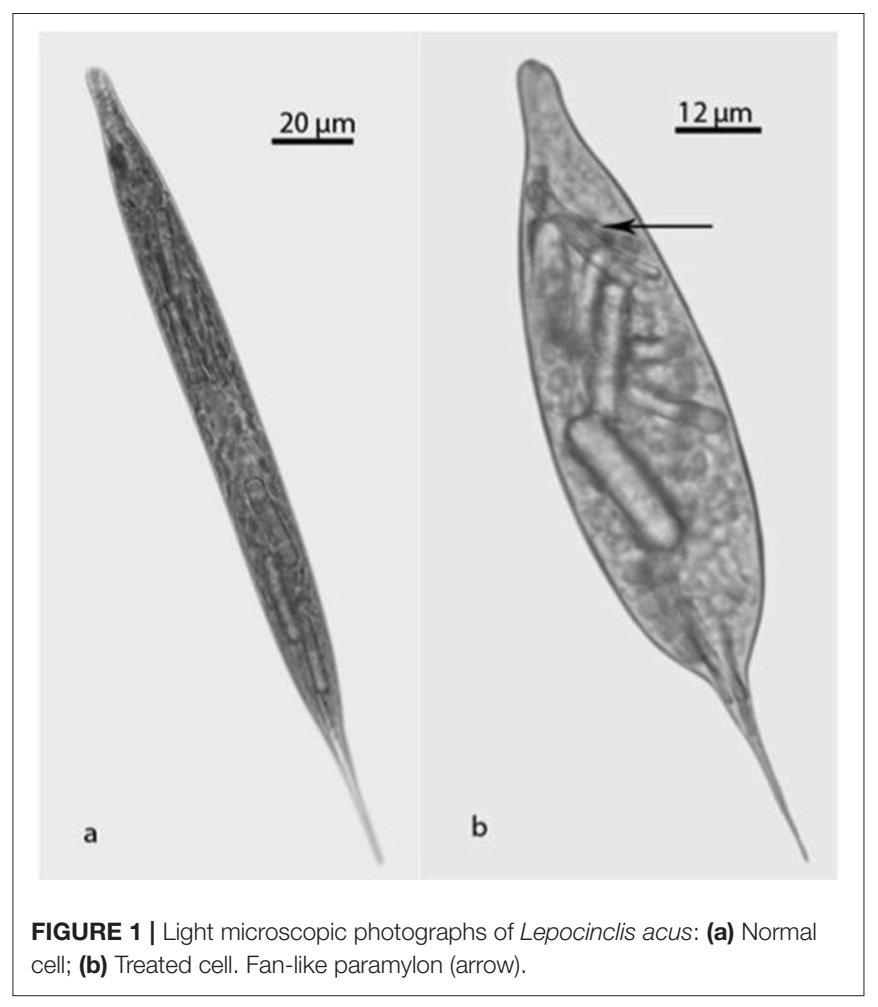


tube. To compare the mean between control tubes and treated tubes a Student $t$-test was performed using a SigmaPlotV12.

An aliquot of the cell suspension was fixed with $3 \%$ formaldehyde solution for light microscopy and the rest was used for TEM and SEM observations. Light microscopy studies were performed with an Olympus BX50 microscope equipped with a digital camera Olympus C-7070 Wide Zoom on control and treated specimens. Control and altered cells were counted and measured.

\section{Transmission Electron Microscopy TEM}

Material for TEM was fixed in (i) $2 \%$ glutaraldehyde in filtered culture medium, and (ii) $2 \%$ glutaraldehyde in $0.05 \mathrm{M} \mathrm{Na}$ cacodylate buffer. In both cases, material was post-fixed in $1 \%$ osmium tetroxide, dehydrated in acetone series and embedded in Spurr resin (Spurr, 1969). Sections 90-100 nm thickness and gold color were cut with a diamond knife (Diatome Ltd, Bienne, Switzerland) in a Reichert-Jung Ultracut UM2 (C. Reichert Optische Werke, Wien, Austria). They were stained with $1 \%$ aqueous solution of uranyl acetate for $40^{\prime}$ and Reynolds lead citrate for $30^{\prime \prime}$. Then they were examined using a JEOL 100 CX-II electron microscope (Jeol Ltd, Akishima, Tokio, Japan) at the Centro Científico y Tecnológico de Bahía Blanca (CCTBB, CONICET). The terminology used to describe pellicle morphology defined by Leander and Farmer (2001) was followed in this analysis.

\section{Scanning Electron Microscopy SEM}

Samples were pelleted and fixed in the same fixatives used for TEM. Cells were rinsed twice with distilled water and filtered onto polycarbonate membranes $(3 \mu \mathrm{m}$ pore size). The cells adsorbed to the membranes were dehydrated in a graded ethanol series (30-100\%, $15 \mathrm{~min}$ each) and then, critical-point-dried in liquid $\mathrm{CO}_{2}$. The filters were sputter-coated with Au-Pd for $6 \mathrm{~s}$ and examined Specimens were photographed in a ZEISS SUPRA 40 Scaning Electron Microscopy from the Service of CMA (FCEN, UBA). The terminology used to describe pellicle morphology defined by Leander and Farmer (2001) was followed in this analysis.

\section{RESULTS}

The measurements of the 100 cells from each of the five-control tube resulted in mean values of $258,286,300,268$, and $315 \mu \mathrm{m}$ length and $17,17,6,6$, and $14 \mu \mathrm{m}$ width. Thus, $97 \%$ of the control cultures cells dimensions can be considered as normal, 65-300 $\mu \mathrm{m}$ length, 7-28 $\mu \mathrm{m}$ width, with 7-20 length/width ratio. The measurements of the 100 cells from each of the five-treated tube resulted in mean values of 185, 246, 190, 260, and 222 length and $34,52,54,50$, and 61 width. In treated cultures (Figure 1b) $75 \%$ of the cells were $221 \mu \mathrm{m} \pm 33$ length, $50 \mu \mathrm{m} \pm 10$ width with a mean length/width ratio of $6 \pm 2$. The differences measured between these two groups were significant, $t=3,582$, $d f=8$, $p<0.01$ (length) and $t=7,472 d f=8$ and $p<<0.001$ (width).

Significant differences were also observed in the rod shape paramylon bodies. In treated cells a remarkable increase in the number and size of paramylon grains was observed which determined important changes in their shape from flat to ovoid.

Some bodies of the paramylon take a "fan-like" shape near the apical end (Figure 1b, arrow). Dimensions of rod paramylon bodies range from $45 \mu \mathrm{m}$ length, $3 \mu \mathrm{m}$ width to $54 \mu \mathrm{m}$ length, 7 width, the "fan-like" paramylon showed a bent shape.

TEM studies (Figures 2, 3) showed ultrastructural differences between normal and treated cells. Transmission electron micrographs of the transversal section, showed differences in the pellicle between treatments (Figure 2). The normal cells had a continuous contour whereas treated cells showed distinct articulation zones due to a clear change in the pellicle strips course; the almost longitudinal pellicle strips regular orientation (Figure 2a) became helical (Figure 2b).

Lepocinclis acus strips in normal cells were flat (2.3$2.9 \mu \mathrm{m}$ wide) and each one had a thick submembrane layer $(0.075-0.1 \mu \mathrm{m})$. They had robust-type frames with a slight median depression and an elaborated cross-section. Teeth-like projections extended below most of the arch increasing the undeformable aspect of the structure. These projections could be clearly seen on the superficial section of the control pellicle (Figures 2a, arrows). Treated cells showed the same pellicle ultrastructure as control cells, including strip shape. However, all the specimens studied had immature strips (new formed strips) between the old ones (Figures $\mathbf{2} \mathbf{b}-\mathbf{d}$ ). This replication was more evident in cell anterior ends (Figures 2e,f, 3c,d), in which bodies significantly increased with respect to normal dimensions (8-10 to $17-21 \mu \mathrm{m})$. As regards the number of strips, L. acus usually has a maximum of 28-36; this number increased to $48-54$ in treated cells.

It was also observed that cells widened along the transversal axis, maintained their flattened shape in the apical and lateral views. This was confirmed by SEM studies (Figure 4) where the new strips can be distinguished on the surface of the cells, new ones developed among old ones (arrows).

Treated cells showed numerous vacuoles containing electron dense inclusions and membranes whorls located close to the pellicle (Figure 2b), and several mitochondrial profiles (Figures 2g,h). Besides these, the ultrastructure of chloroplasts (Figure 3a) suffers alterations. In treated cells, the thylakoid lamellae were not easily detected due to their incipient disorganization (Figure $\mathbf{3 b}$ ). This fact would correlate with the modification in cell color observed through light microscope, from dark to light green in living cells.

Control cells showed several little spherical and few rod shape paramylon bodies, irregularly distributed (Figure 3c). Instead, treated cells exhibited a high number and extremely large paramylon grains that occupied great part of the cytoplasm (Figure 3d).

The ovoid nucleus showed very few chromosomes and one or several endosomes in both control (Figure 5a) and treated cells. However, no changes were seen in the nucleus besides its displacement from center to the lateral in treated cells (Figures 2g, 5b), clearly displaced by paramylon bodies.

Cellular breaking was observed both in cultures and in natural samples from organically enriched fresh water bodies. Both had numerous free paramylon grains that came from broken cells, 


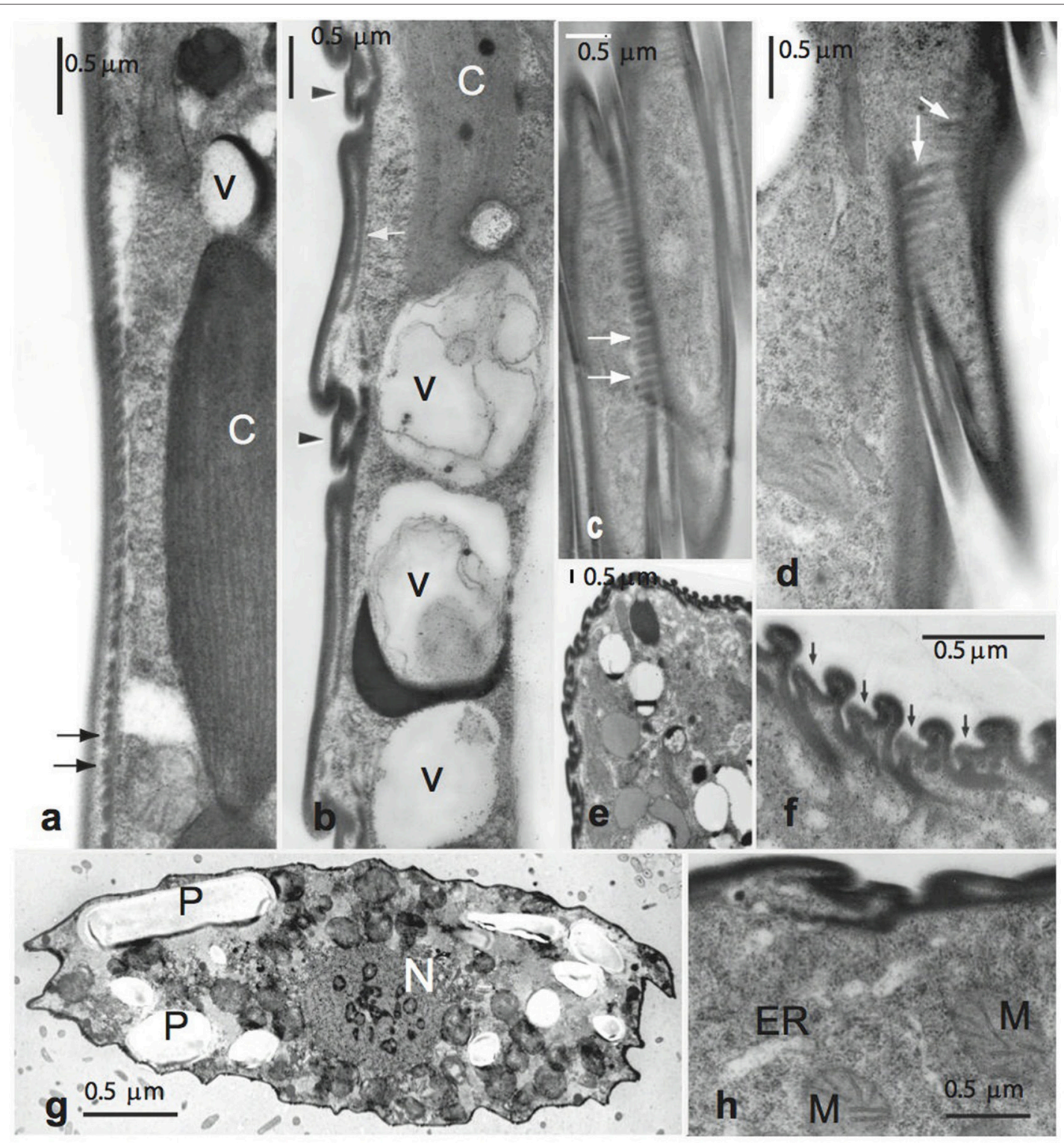

FIGURE 2 | Transmission electron micrographs of Lepocinclis acus. (a) Control cell showing a continuous contour and the tooth-like projections in transverse section (arrows) Normal chloroplast (C). (b-h) Treated cells. (b) New strips between the old ones (arrowheads) and vacuoles $(\mathrm{V}$ ) containing electron dense material and membranes were observed. (c,d) Tangential sections showing the periodicity and thickness of the tooth-like projections (arrows). (e) Anterior end of a cell showing clearly the new formed strips. (f) Detail of figure (e), arrows indicate the new strips. (g) Transversal section showing mitochondrial profiles $(\mathrm{M})$, the nucleus $(\mathrm{N})$ and paramylon grains (P). (h) Detail of the mitochondrial profiles (M) and endoplasmic reticulum (ER) distributed near to the pellicle.

thus suggesting that cells might support deformation only to a certain extent.

\section{DISCUSSION}

Lepocinclis acus is a typical euglenoid specimen with rigid or semi-rigid pellicle and fusiform cells that may suffer slight body deformation only by torsion or incurvation during its displacement. However, specimens studied in our bioassays showed strong morphological changes in response to organic matter enrichment of the culture medium.
The basic pellicular substructure observed in treated L. acus in this study agreed with that of normal specimens (Mignot, 1965; Bricheux and Brugerolle, 1986). However, even though treated cells did not show basic strip substructural changes, they clearly exhibited pellicular strip replication. The adjacent number of vacuoles enclosing membranes may probably be involved in the increase of strip number, supplying the material to originate new pellicle components.

In euglenoids, this new pellicular strip development is related to cell growth (Hofman and Bouck, 1976) and cell division (Chaley et al., 1977). In fact, it is often used as a marker for 


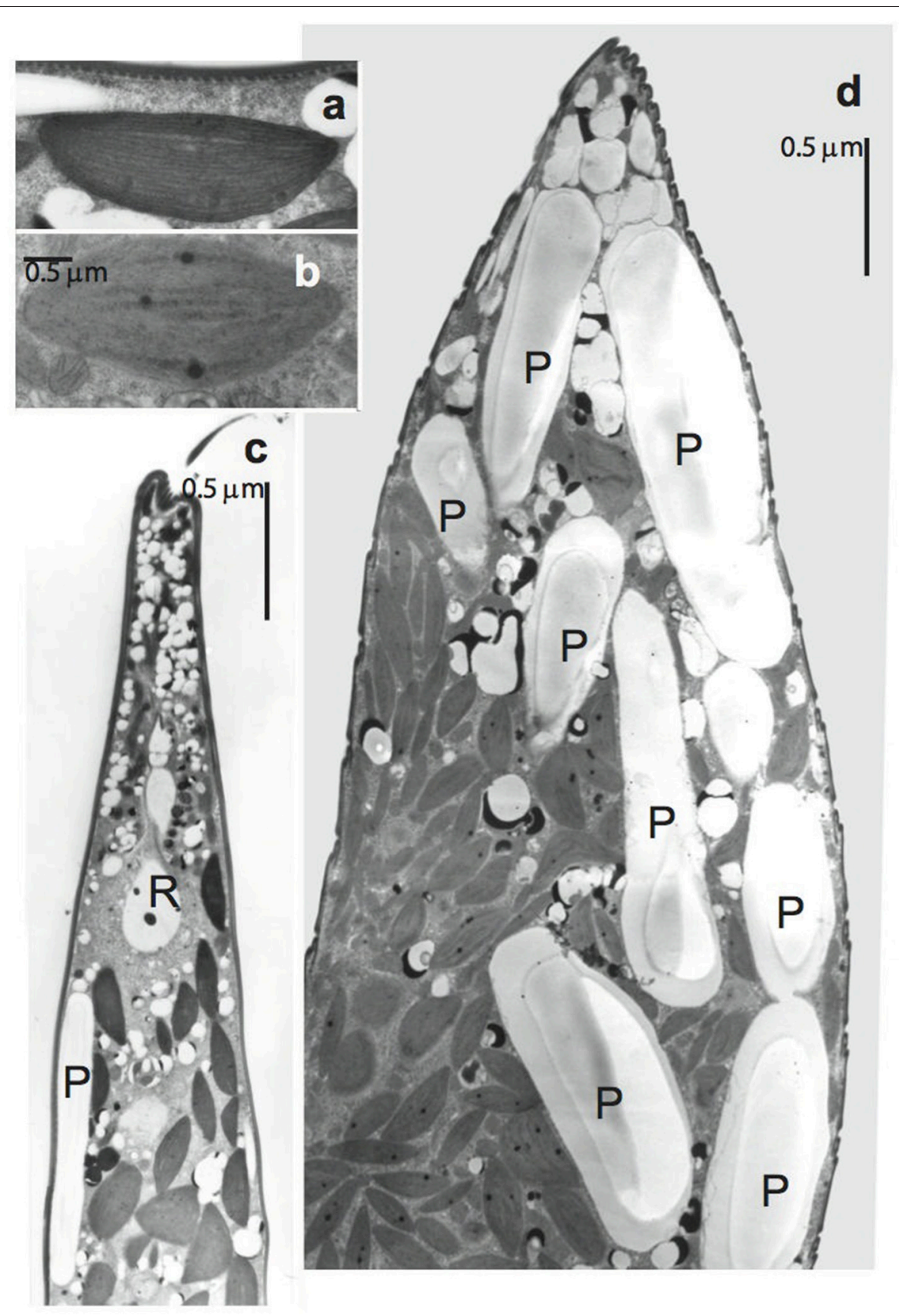

FIGURE 3 | Transmission electron micrographs of Lepocinclis acus. (a,b) Details of chloroplasts. (a) Control cell. (b) Treated cell showing the incipient thylakoid lamellae disorganization. (c) Longitudinal section through the anterior portion of control cell. Note several little spherical and few rod shape paramylon bodies (R). (d) Longitudinal section through the anterior portion of treated cell. Note numerous and extremely large paramylon grains (P).

the onset of mitosis, except in the genus Entosiphon in which pellicular strip replication occurs later in division (Triemer, 1988).

During mitosis, the number of euglenoids strips duplicates, the nucleus migrates toward the base of the reservoir, and the persistent nucleolus elongates. Our studies on $L$. acus showed clear strip replication. The nucleus, however, was far from the reservoir and located central or laterally in the middle or posterior portion of the cell, whereas the size of the nucleolus did not increase. Sometimes, in old cultures the cells often have strip replication without cytokinesis. Nevertheless, to our knowledge there is no information in the literature on this behavior in short term cultures $(48 \mathrm{~h}$ ), as shown in our study. Moreover, no division stages were observed through light microscopy in cells cultured in the enriched medium. 


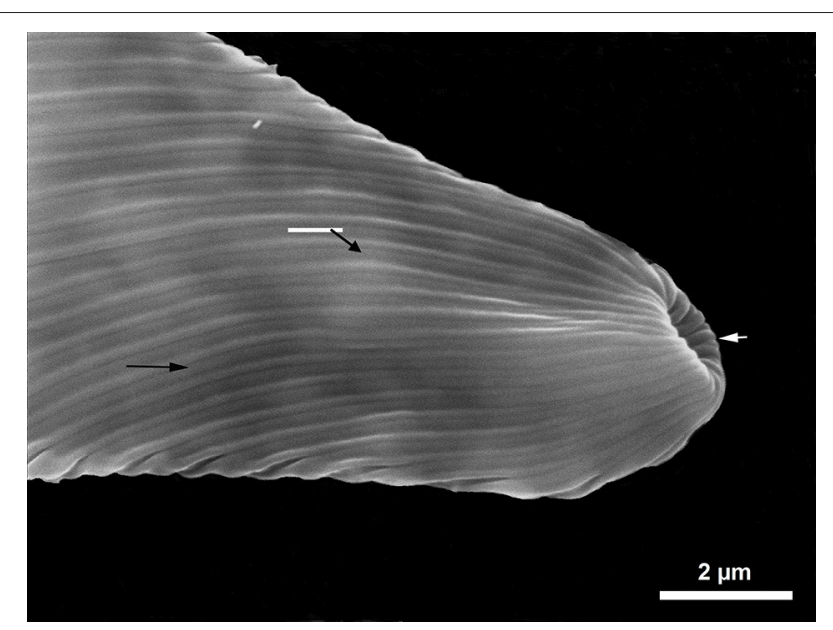

FIGURE 4 | SEM photography new strips (arrows) can be observed between old ones.

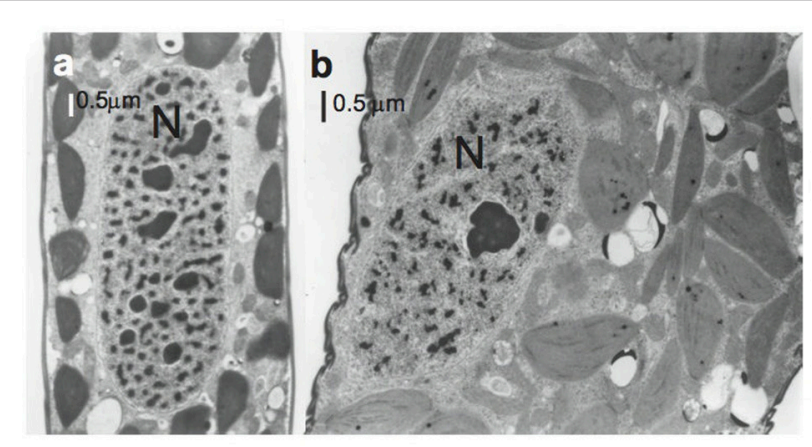

FIGURE 5 | Electron micrographs of Lepocinclis acus nuclei. (a) Control cell where the nucleus $(\mathrm{N})$ is centrally located. (b) Treated cell where the nucleus is laterally located.

These results suggest that cell deformation might be facilitated by the development of emerging new strips within the articulation zones between the old ones, whereas the normal substructure of the latter is maintained. As a consequence, pellicle strips disposition is modified from longitudinal to helical, and cell length/width ratio decreases without affecting cellular thickness. It is worth mentioning that the occurrence of strip duplication with no following cytokinesis agrees with the mechanism proposed by Leander and Farmer (2001) to account for strips number increase during euglenoids evolution.

According to our observations, cell deformation would be induced to a certain extent after which lysis occurs.

This response to an increase in cell volume was different in elastic species such as Euglena gracilis (Bertaux and Valencia, 1973) or a rigid one as Phacus brachykentron (Nannavecchia et al., 2014), where strips became wider, but no replication were observed. The existence of these different development response patterns in respect to similar environmental conditions could be an important evolutionary difference among euglenoids.

Likewise, when paramylon synthesis was experimentally increased in E. gracilis (Kiss et al., 1986), strips became wider but did not increase in number, in response to the great accumulation of paramylon grains in its cells.

On the other hand, the particular combination of morphological and ultrastructural modifications observed in L. acus cultured in enriched medium added to those described in P. brachykentron (Nannavecchia et al., 2014), raises serious questions and doubts on the validity of the usual euglenoids systematic characters as cell dimensions, number and paramylon shape. Several molecular studies have shown that a revision of the euglenoids taxonomy is necessary (Linton et al., 2000, 2010; Marin et al., 2003; Nudelman et al., 2003; Brosnan et al., 2005; Triemer et al., 2006; Kosmala et al., 2009; Karnkowska-Ishikawa et al., 2012, 2013; Kim et al., 2013, 2015; Kim and Shin, 2014; Łukomska-Kowalczyk et al., 2015; Bicudo and Menezes, 2016).

In addition to these publications and what many authors have previously reported (Van Oye, 1924; Conrad, 1943; Conforti, 1998; Bauer et al., 2012), it is possible to confirm based on our observations, once again, that paramylon grains have little diagnostic value as species-specific characters in euglenoids. Their morphology and number, as well the cell dimensions can change based on environmental conditions, so these three diagnostic characters should be taken with caution when describing new or identifying know species.

As regards to cell dimensions, which are usually used in systematic determination, we verified that they were strongly affected by external conditions, thus suggesting that different species may turn out to be just ecomorphs of the same taxon.

Moreover, since strip replication may occur independently of cytokinesis, it would be erroneous to consider the number of strips in a clone as a valid systematic character in euglenoids (Mignot, 1965; Sommer and Blum, 1965; Mignot et al., 1987). In asexual organisms as the ones studied in which systematic determination is mainly based on morphological characteristics, these changes are particularly troubling. Therefore, a thorough and careful revision of the systematics of this group becomes essential. Even though recent literature contributed to enhance our understanding of euglenoids, there are still many unexplored issues that need to be addressed.

Lastly, these cellular changes were very fast, observed within $48 \mathrm{~h}$ of bioassay. Therefore, any action leading to a significant increase of organic concentration in the water will rapidly affect $L$. acus morphology. The algae were very sensitive to pollution in a short time of exposure and survived under adverse conditions showing cell alterations. This would imply that the presence of these altered cells in nature could be used as a good environmental bioindicator. Additionally, we recorded broken cells in cultures, as was reported in organically enriched samples from fresh water bodies (Conforti, 1998), so large input of organic matter can be extremely harmful to this species, greatly reducing their abundance by cell lysis.

\section{AUTHOR CONTRIBUTIONS}

VC: conducted the research, results evaluation, and writing; LR: conducted bioassays, results evaluation and writing; PL: conducted microscopic studies and writing. 


\section{ACKNOWLEDGMENTS}

This investigation was supported by grants to VC, UBACYT 20020130100201BA and CONICET - PIP 11220130100674. The authors are grateful to Dr. Cristian Solari for the English

\section{REFERENCES}

Bauer, D. E., Conforti, V., Ruiz, L., and Gómez, N. (2012). An in situ test to explore the responses of Scenedesmus acutus and Lepocinclis acus as indicators of the changes in water quality in lowland streams. Ecotoxicol. Environ. Saf. 77, 71-78. doi: 10.1016/j.ecoenv.2011.10.021

Bertaux, O., and Valencia, R. (1973). Blocage de la division cellulaire et malformations induites par carence $\mathrm{B}_{12}$ chez des cellules synchrones de Euglena gracilis Z. C. R. Acad. Sci. Paris 276, 753-756.

Bicudo, C., and Menezes, M. (2016). Phylogeny and classification of Euglenophyceae: a brief review. Front. Ecol. Evol. 4:17. doi: 10.3389/fevo.2016.00017

Bre, M. H., and Lefort-Tran, M. (1978). Induction et réversibilité des évènements cuticulaires par carence et réalimentation en vitamine B12 crez Euglena gracilis. J. Ultrastruct. Res. 64, 362-376. doi: 10.1016/S0022-5320(78)90044-8

Bricheux, G., and Brugerolle, G. (1986). The membrane cytoskeleton complex of euglenoids. I. Biochemical and immunological characterization of epiplasmic proteins in E. acus. Eur. J. Cell Biol. 40, 150-159.

Brosnan, S., Brown, P. J., Farmer, M. A., and Triemer, R. E. (2005). Morphological separation of the euglenoid genera Trachelomonas an Strombomonas (Euglenophyta) based on lorica development and posterior strip reduction. J. Phycol. 41, 590-605. doi: 10.1111/j.1529-8817.2005.00068.x

Chaley, N., Lord, A., and Fontaine, G. (1977). A light and electron microscopic study of nuclear structure throughout the cell cycle in the euglenoid Astasia longa. J. Cell Sci. 27, 23-45.

Conforti, V. (1991). Taxonomic study of the Euglenophyta of a highly polluted river of Argentina. Nov. Hedw. 53, 73-98.

Conforti, V. (1998). Morphological changes of Euglenophyta in response to organic enrichment. Hydrobiology 129, 277-285. doi: 10.1023/A:1017049910481

Conforti, V., Alberghina, J., and Gonzalez Urda, E. (1995). Structural changes and dynamics of the phytoplankton along a highly polluted lowland river of Argentina. J. Aqua. Ecosyst. 4, 59-75. doi: 10.1007/BF00043344

Conrad, W. (1943). Remarques sur le genre Phacus Duj., (1841). Bull. Mus. Roy. Hist. Nat. Belg. 19, 1-16.

Dokulil, M. (1996). "Evaluation of eutrophication potential in rivers: The Danube example, a review," in Use of Algae for Monitoring Rivers II, eds B. A. Whitton and E. Rott (Innsbruck: University of Innsbruck), 173-179.

Esson, H. J., and Leander, B. S. (2006). A model for the morphogenesis of strip reduction patterns in phototrophic euglenids: evidence for heterochrony in pellicle evolution. Evol. Dev. 8, 378-388. doi: 10.1111/j.1525-142X.2006.00110.x

Esson, H. J., and Leander, B. S. (2008). Novel pellicle surface patterns on Euglena obtusa Schmitz (Euglenophyta), a euglenophyte from a benthic marine environment: implications for pellicle development and evolution. J. Phycol. 43, 132-141.

Haughey, A. (1970). Notes on Euglena acus Ehrenberg from sewage treatment ponds. Br. Phycol. J. 4, 97-102. doi: 10.1080/00071617000650131

Hofman, C., and Bouck, G. B. (1976). Immunological and structural evidence for patterned intussusceptive surface growth in a unicellular organism. J. Cell Biol. 69, 693-715. doi: 10.1083/jcb.69.3.693

Karnkowska-Ishikawa, A., Milanowski, R., Triemer, R. E., and Zakryś, B. (2013). A redescription of morphologically similar species from the genus Euglena: E. laciniata, E. sanguinea, E. sociabilis, and E. splendens. J. Phycol. 49, 616-626. doi: $10.1111 /$ jpy. 12072

Karnkowska-Ishikawa, A., Milanowski, R., Triemer, R. E.; and Zakryś, B. (2012). Taxonomic revisions of morphologically similar species from two euglenoid genera: Euglena (E. granulata and E. velata) and Euglenaria (Eu. anabaena, Eu. caudata, and Eu. clavata). J. Phycol. 48, 729-739. doi: 10.1111/j.1529-8817.2012.01140.x text revision, Lic. Luca Schenone for the statistic advice and to Florencia Marconi by the assembly of the plates. VC and PL are research members of CONICET (Consejo Nacional de Investigaciones Científicas y Técnicas de la República Argentina).

Kim, J. I., and Shin, W. (2014). Molecular phylogeny and cryptic diversity of the genus Phacus (Phacaceae, Euglenophyceae) and the descriptions of seven new species. J. Phycol. 50, 948-959. doi: 10.1111/jpy.12227

Kim, J. I., Linton, E. W., and Shin, W. (2015). Taxon-rich multigene phylogeny of the photosynthetic euglenoids (Euglenophyceae). Front. Ecol. Evol. 20:98. doi: 10.3389/fevo.2015.00098

Kim, J. I., Shin, W., and Triemer, R. E. (2013). Phylogenetic reappraisal of the genus Monomorphina (Euglenophyceae) based on molecular and morphological data. J. Phycol. 49, 82-91. doi: 10.1111/jpy.12018

Kiss, J., Vasconcelos, A., and Triemer, R. (1986). Paramylon synthesis chloroplast structure associated with nutrient levels in Euglena (Euglenophyceae). J. Phycol. 22, 327-333. doi: 10.1111/j.1529-8817.1986.tb00031.x

Kosmala, S., Karnkowska-Ishikawa, A. M., Ilanowski, R., Kwiatowski, J., and Zakrys, B. (2009). Phylogeny and systematics of species from the genus Euglena (Euglenophyceae) with axial, stellate chloroplasts based on morphological and molecular data - new taxa, emended diagnoses and epitypifications. J. Phycol. 45, 464-481. doi: 10.1111/j.1529-8817.2009.00653.x

Lackey, J. B. (1968). “Ecology of Euglena," in The Biology of Euglena, Vol. 1, ed D. Buetow (New York, NY: Academic Press), 27-44.

Leander, B. S. (2004). Did trypanosomatid parasites have photosynthetic ancestors? Trends Microbiol. 12, 251-258. doi: 10.1016/j.tim.2004.04.001

Leander, B. S., and Farmer, M. A. (2001). Comparative morphology of the euglenoid pellicle. II. Diversity of the strip substructure. J. Eukaryot. Microbiol. 48, 204-219. doi: 10.1111/j.1550-7408.2001.tb00304.x

Linton, E. W., Karnkowska-Ishikawa, A., Kim, J. I., Shin, W., Bennett, M., Kwiatowski, J., et al. (2010). Reconstructing euglenoid evolutionary relationships using three genes: nuclear SSU and LSU, and chloroplast 16s rDNA sequences and the description of Euglenaria gen. nov. (Euglenophyta). Protist 161, 603-619. doi: 10.1016/j.protis.2010.02.002

Linton, E. W., Nudelman, M. A., Conforti, V., and Triemer, R., E (2000). A molecular analysis of the genus Euglena (Euglenophyta) using SSU rDNA. J. Phycol. 36, 740-746. doi: 10.1046/j.1529-8817.2000.99226.x

Łukomska-Kowalczyk, M., Karnkowska, A., Milanowski, R., Łach, Ł., and Zakryś, B. (2015). Delimiting species in the Phacus longicauda complex (Euglenida) through morphological and molecular analyses. J. Phycol. 51, 1147-1157. doi: 10.1111/jpy.12352

Marin, B., Palm, A., Klingberg, M., and Melkonian, M. (2003). Phylogeny and taxonomic revision of plastid - containing Euglenophytes based on SSU rDNA sequence comparisons and synapomorphic signatures in the SSU rRNA secondary structure. Protist 154, 99-145. doi: 10.1078/1434461037649 28521

Mignot, J. P. (1965). Ultrastructure de Eugléniens, I. Etude de la cuticule chez différentes espèces. Protistologica 1, 1-15.

Mignot, J., Brugerolle, G., and Bricheux, G. (1987). Intercalary strip development and dividing cell morphogenesis in the euglenoid Cyclidiopsis acus. Protoplasma 139, 51-65. doi: 10.1007/BF01417535

Munawar, M. (1972). Ecological studies of Eugleninae in certain polluted and unpolluted environments. Hydrobiologia 39, 307-320. doi: 10.1007/BF00046647

Nannavecchia, P., Tolivia, A., and Conforti, V. (2014). Ultrastructural alterations in Phacus brachykentron (Euglenophyta) as a result of organic matter excess in the culture medium. Ecotoxicol. Environ. Saf. 101, 36-41. doi: 10.1016/j.ecoenv.2013.12.007

Nozaki, H. (2005). A new scenario of plastid evolution: plastid primary endosymbiosis before the divergence of the "Plantae," emended. J. Plant Res. 118, 247-255. doi: 10.1007/s10265-005-0219-1

Nudelman, M. A., Rossi, M. S., Conforti, V., and Triemer, R. E. (2003). Phylogeny of Euglenophyceae based on small subunit rDNA sequences: taxonomic implications. J. Phycol. 39, 226-235. doi: 10.1046/j.1529-8817.2003.02075.x 
O'Farrell, I., Lombardo, R. J., Tezanosn Pinto, P., and Loez, C. (2002). The assessment of water quality in the lower Luján River (Buenos Aires, Argentina): phytoplankton and algal bioassays. Environ. Pollut. 120, 207-218. doi: 10.1016/S0269-7491(02)00136-7

Paul, M., and Meyer, J. (2001). Streams in the urban landscape. Annu. Rev. Ecol. Syst. 32, 333-365. doi: 10.1146/annurev.ecolsys.32.081501.114040

Paul, M., and Meyer, J. (2008). "Streams in the urban landscape," in Urban Ecology, Section III, eds J. M. Marzluff, W. Endlicher, G. Bradley, U. Simon, E. Shulenberger, M. Alberti, C. Ryan, and C. ZummBrunen (New York, NY: Springer), 207-232.

Pringsheim, E. G. (1946). The biphasic or soil-water cultured method for growing algae and flagellates. J. Ecol. 33, 193-204. doi: 10.2307/2256465

Rosowski, J. (2003). "Photosynthetic euglenoids," in Freshwater Alagae of North America, eds J. D. Wehr and R. G. Sheath (New York, NY: Academic Press), $383-422$.

Sommer, J. R., and Blum, J. J. (1965). Cell division in Astasia longa. Exp. Cell Res. 3, 504-527. doi: 10.1016/0014-4827(65)90054-6

Spurr, A. R. (1969). A low viscosity epoxy resin embedding medium for electron microscopy. J. Ultrastr. Res. 26, 31-43. doi: 10.1016/S0022-5320(69)90033-1
Triemer, R. E. (1988). Ultrastructure of mitosis in Entosiphon sulcatum (Euglenida). J. Protozool. 35, 231-237. doi: 10.1111/j.1550-7408.1988.tb04330.x Triemer, R. E., Linton, E., Shin, W., Nudelman, M., Brosnan, S., Monfils, A., et al. (2006). Phylogeny of the Euglenales based upon combined SSU and LSU r DNA sequence comparisons and description of Discoplastis gen. nov., (Euglenophyta). J. Phycol. 42, 731-740. doi: 10.1111/j.1529-8817.2006.00219.x Van Oye, P. (1924). Note sur l' Euglena acus. Ehr. Bull. Soc. Roy. Bot. Bel. 56, $124-132$.

Conflict of Interest Statement: The authors declare that the research was conducted in the absence of any commercial or financial relationships that could be construed as a potential conflict of interest.

Copyright (C) 2017 Conforti, Ruiz and Leonardi. This is an open-access article distributed under the terms of the Creative Commons Attribution License (CC BY). The use, distribution or reproduction in other forums is permitted, provided the original author(s) or licensor are credited and that the original publication in this journal is cited, in accordance with accepted academic practice. No use, distribution or reproduction is permitted which does not comply with these terms. 